\title{
RESEARCH
}

\section{Circ-Tulp4 promotes $\beta$-cell adaptation to lipotoxicity by regulating soat1 expression}

\author{
Liting Wu(D1,*, Li Xiong1,*, Jin Li1,2, Zishan Peng1, Luyao Zhang1, Peijie Shi, Yingying Gong1,2 and Haipeng Xiao \\ 'Department of Endocrinology and Metabolism, The First Affiliated Hospital of Sun Yat-sen University, Guangzhou, Guangdong, China \\ 2Department of Geriatrics, The First Affiliated Hospital of Sun Yat-sen University, Guangzhou, Guangdong, China
}

Correspondence should be addressed to Y Gong or H Xiao: gongyy5@mail.sysu.edu.cn or Xiaohp@mail.sysu.edu.cn

*(L Wu and L Xiong contributed equally to this work)

\begin{abstract}
This study aimed to identify circular RNAs differentially expressed in the islets of type 2 diabetes (T2DM) models and clarify their roles in the control of $\beta$-cell functions. Circular RNAs dysregulated in the islets of diabetic $\mathrm{db} / \mathrm{db}$ mice were identified by high-throughput RNA sequencing. Then, the expression level of the selected circular RNA circ-Tulp4 was confirmed by real-time PCR in the islets of diabetic models and Min6 cells. MTS, EdU, western blot, flow cytometric analysis, and luciferase assay were performed to investigate the impact of circ-Tulp4 on $\beta$-cell functions. This study identified thousands of circular RNAs in mouse pancreatic islets. The circ-Tulp4 level significantly decreased in the diabetic models and altered in the Min6 cells under lipotoxic condition. The modulation of circ-Tulp4 level in Min6 cells regulated cell proliferation. Furthermore, an interaction was demonstrated between circ-Tulp4 and miR-7222-3p, which suppressed the expression of cholesterol esterification-related gene, sterol O-acyltransferase 1 (SOAT1). The accumulation of soat1 activated cyclin D1 expression, thus promoting cell cycle progression. These findings showed that circ-Tulp4 regulated $\beta$-cell proliferation via miR-7222-3p/soat1/cyclin D1 signaling. Our research suggested that circ-Tulp4 might be a potential therapeutic intervention for T2DM. Besides, soat1 might be important for $\beta$-cell adaptation to lipotoxicity.
\end{abstract}

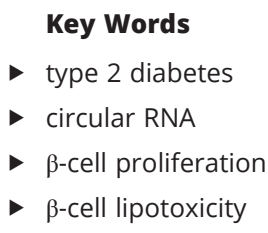

Journal of Molecular Endocrinology (2020) 65, 149-161

\section{Introduction}

Pancreatic $\beta$ cells are specialized insulin-secreting cells responsible for the control of blood glucose levels (Ferrannini \& Mari 2004). $\beta$-Cell mass reduction and/or dysfunction can lead to hyperglycemia and the development of diabetes (Heit et al. 2006). Type 2 diabetes (T2DM) is characterized by insufficient $\beta$-cell function under obesity-induced insulin resistance (Kahn et al. 2006). In the prediabetic condition, $\beta$ cells accelerate their proliferation rates to compensate for the $\beta$-cell loss caused by apoptosis (Prentki \& Nolan 2006, Montanya
\& Téllez 2009). However, prolonged exposure to high concentrations of glucose and free fatty acids increase $\beta$-cell apoptosis and inhibit proliferation, eventually reducing $\beta$-cell mass and inducing T2DM manifestation (Busch et al. 2005, Prentki \& Nolan 2006, Schofield \& Sutherland 2012). Therefore, a better understanding of the molecular mechanisms underlying $\beta$-cell adaptation is vital for designing new therapeutics for T2DM.

Previous transcriptome analyses have unveiled that a large number of non-coding RNAs are expressed in

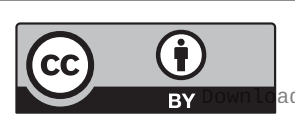

This work is licensed under a Creative Commons Attribution 4.0 International License. 
$\beta$ cells (Nesca et al. 2013, Motterle et al. 2017, Stoll et al. 2018, Xiong et al. 2020). Available evidence indicates that small RNAs (miRNA) and long non-coding RNAs play key roles in regulating $\beta$-cell functions (Guay et al. 2012, Nesca et al. 2013, Motterle et al. 2017). However, experimental data linking circular RNAs (circRNAs) to $\beta$-cell functions are limited.

Recently, the advancement of biotechnology has increased the understanding of the expression and function of circRNAs (Suzuki et al. 2006, You et al. 2015, Xu et al. 2017). circRNAs contain mainly exonic sequences, which are back-spliced by spliceosome mediation (Barrett et al. 2015, Starke et al. 2015). Because of the circular secondary structure, circRNAs are more stable than linear transcripts (Suzuki et al. 2006). Furthermore, the expression of circRNAs generally exhibits cell-type and tissue-specific patterns (Salzman et al. 2013, Enuka et al. 2016). circRNAs have been frequently reported to participate in diverse gene-regulatory mechanisms, and their dysregulations have been implicated in health and disease (Zhang et al. 2013, 2018b, Du et al. 2016, 2017). In diabetes, circHIPK3 and CDR1as have been shown to regulate $\beta$-cell proliferation and insulin secretion in mouse islets by sponging multiple miRNA and modulating the activity of miRNA on other target genes (Xu et al. 2015, Stoll et al. 2018). However, the functional characterization of most discovered circRNAs in $\beta$ cells remains to be elucidated.

In this study, whole transcriptome sequencing was used to explore the global variations in islet transcriptomes in $\mathrm{db} / \mathrm{db}$ diabetic mice and $\mathrm{db} / \mathrm{m}$ healthy control mice. Hundreds of circRNAs displayed expression changes, and circ-Tulp4 showed significant downregulation in diabetic mouse islets and Min6 cell lines under lipotoxic condition. Further experiments indicated that modulating the expression of circ-Tulp4 in Min6 cells desensitized $\beta$ cells to lipotoxicity. This study proved that circ-Tulp4 promoted $\beta$-cell function by sponging miR-7222-3p and regulating the expression of cholesterol esterificationrelated gene, sterol O-acyltransferase 1 (SOAT1) and cyclin D1 signaling.

\section{Materials and methods}

\section{Animal experiments}

Animal experiments were conducted following relevant Chinese institutional laws and guidelines and were approved by the local ethics committee of Sun Yat-sen University. All mice were obtained from the Model Animal Research Center of Nanjing University (Nanjing, China).
Five-week-old male $\mathrm{db} / \mathrm{db}$ diabetic mice (BKS. Cg-Dock7m+/+Leprdb/Nju) and age-matched nondiabetic male littermate $\mathrm{db} / \mathrm{m}$ mice were placed on a normal diet. After 5 weeks, they were sacrificed for islets isolation. Five-week-old male C57BL/6J mice were placed on a normal control diet (NFD) (D12450J, Research Diets, New Brunswick, NJ, USA) or high-fat diet (HFD) (D12492, Research Diets) for 8 months until they were sacrificed for islets isolation.

The mice were killed with phenobarbital sodium (40 mg/100 g body weight) and $3 \mathrm{~mL}$ of PBS containing $0.4 \mathrm{mg} / \mathrm{mL}$ collagenase $\mathrm{P}$ (Roche) was immediately injected into the bile duct. Islets were isolated by collagenase digestion followed by purification on Histopaque (Sigma Aldrich) density gradient and used directly for RNA extraction.

\section{Culture and treatment of cells}

Min6 cells, obtained from the American Type Culture Collection (ATCC), were cultured in a mixture containing DMEM, 15 (v/v) fetal bovine serum (FBS), $100 \mathrm{mg} / \mathrm{mL}$ streptomycin, $100 \mathrm{U} / \mathrm{mL}$ penicillin, and $5 \mu \mathrm{L} / \mathrm{L}$ $\beta$-mercaptoethanol. HEK293 cells were obtained from ATCC and cultured in DMEM supplemented with 10 (v/v) FBS. Passage numbers of Min6 cells used for experiments were 5-20, while HEK 293 cells were 3-5.

For palmitate acid (PA) treatment, $0.5 \mathrm{mmol} \mathrm{PA}$ (Sigma) was dissolved in $5(\mathrm{w} / \mathrm{v})$ BSA $(5 \mathrm{~mL})$ and $0.1 \mathrm{M}$ $\mathrm{NaOH}(5 \mathrm{~mL})$ to make a stock solution $(50 \mathrm{mM})$. The lipotoxic condition was induced with PA $(0.5 \mathrm{mM})$ for $24 \mathrm{~h}$. The control cells were exposed to $0.1(\mathrm{w} / \mathrm{v})$ BSA at the same time.

For cytokine treatment, Min6 cells were exposed to cytokine cocktails consisting of IL- $1 \beta$, TNF- $\alpha$, and IFN- $\gamma$ for $24 \mathrm{~h}$ (Sino Biological, China); cytokine cocktail 1 consists of IL-1 $\beta$ ( $5 \mathrm{ng} / \mathrm{mL}), \mathrm{TNF}-\alpha(25 \mathrm{ng} / \mathrm{mL})$ and IFN- $\gamma(25 \mathrm{ng} / \mathrm{mL})$; cytokine cocktail 2 consists of IL-1 $\beta$ (1 ng/mL), TNF- $\alpha(20 \mathrm{ng} / \mathrm{mL})$ and IFN- $\gamma(20 \mathrm{ng} / \mathrm{mL})$. The culture medium treated cells were used as control.

\section{Whole-transcriptome sequencing}

The Hiseq Sequencer platform was used for wholetranscriptome sequencing. The library for sequencing was constructed by removing rRNA from the total RNA of six samples ( $3 \mathrm{db} / \mathrm{m}$ and $3 \mathrm{db} / \mathrm{db}$ mice). Clean reads were obtained by filtering the adaptor sequences, $\mathrm{N}$ bases, and low-quality reads. Then, the reads were mapped to the Mus musculus genome (Build version mm10) using

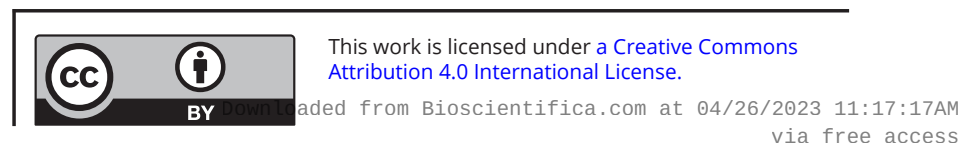


the TopHat program (V2.0.14). The DESeq algorithm was employed to analyze differential expressed genes (Anders $\&$ Huber 2010). The ACFS circRNA prediction pipeline was used for circRNA identification (You \& Conrad 2016). The Gene Ontology and pathway analysis were performed to elucidate biological implications and significant pathways of differentially expressed genes (Ashburner et al. 2000, Draghici et al. 2007). The miRanda tool and RNAhybrid algorithm were used for discovering competing endogenous RNA (ceRNA) relation (Grimson et al. 2007, Friedman et al. 2009, Garcia et al. 2011). Sequence data is available at http://www.ncbi.nlm.nih.gov/geo/query/acc. cgi?acc=GSE138096.

\section{Modulation of gene levels in Min6 cells}

Transfection of microRNA mimics or inhibitors (RiboBio) or siRNAs (RiboBio) to Min6 cells was achieved using the Lipofectamine 3000 reagent (Invitrogen) according to the manufacturer's protocols. The final concentration was 50 nM. Two siRNAs were used simultaneously to avoid offtarget effects. The genes were overexpressed via infection with purified Adeno-associated virus (AAV) in the culture medium. The sequence fragment of circRNA or mRNA was amplified, sequenced, and inserted into AAV pK4ssAAVGFP plasmids to construct the overexpression vectors (Geneseed). The cells were cultured for $48 \mathrm{~h}$ post-gene modulation and processed for subsequent experiments.

\section{Western blot analysis}

Western blot analysis was performed according to a method described in a previous study (Nesca et al. 2013). The membranes were incubated with appropriate diluted primary antibodies overnight and secondary antibodies. The bands were visualized using a chemiluminescent substrate (Invitrogen), and the intensities were quantified using the ImageJ software.

Primary antibodies targeting ki67 (cat\# 2586 Cell Signaling Technology), cleaved caspase-3 (cat\# 9661S Cell Signaling Technology), soat1 (cat\# PA5-76906 Invitrogen), cyclin D1 (cat\# ab.134175 Abcam), $\beta$-actin (cat\# 4967 Cell Signaling Technology), $\beta$-tubulin (cat\# 2128 Cell Signaling Technology) were used in this study.

\section{Measurement of insulin secretion}

Glucose-stimulated insulin secretion (GSIS) assay was performed as previously described (Xiong et al. 2020). To normalize the amount of secreted insulin, the cell number was recalculated, and the insulin secretion was expressed as the concentration of insulin $(\mathrm{ng} / \mathrm{mL})$ secreted per $5 \times 10^{4}$ cells.

\section{Data statistical analysis}

All experiments were repeated at least three times. The results were expressed as either individual data points or mean \pm s.E.M. unless otherwise indicated. The data were compared using the Student's t-test between two groups or ANOVA for more than two groups, followed by Dunnett's multiple comparisons. A $P$ value $<0.05$ was considered statistically significant, which was indicated in the figures.

Methods are shown in the Supplementary Materials and methods (see section on supplementary materials given at the end of this article) in detail.

\section{Results}

\section{RNA-seq analysis of islet circRNAs and mRNA profiling in $\mathrm{db} / \mathrm{db}$ mice}

To investigate the involvement of circRNAs in the regulation of $\beta$-cell dysfunction and the development of T2DM, the transcriptomes of isolated islets were compared using the Hiseq Sequencer platform. The characteristics of the animal models used in this study were presented in Supplementary Fig. 1. Differentially expressed circRNAs were identified by comparing $\mathrm{db} / \mathrm{db}$ and $\mathrm{db} / \mathrm{m}$ samples (10-week-old). The analysis detected about 5000 circRNAs expressed in mouse pancreatic islets, of which 346 circRNAs exhibited significant differences in expression, and 14 showed a significant difference with a fold change $\geq 1.5$. In detail, eight genes were upregulated, whereas six downregulated. The 14 dysregulated circRNAs were plotted in Fig. 1A, B, and C. The chromosomal location and the fold changes of these circRNAs were shown in Supplementary Table 2. The expression of these circRNAs in primary islets were validated using specific divergent primers and Sanger sequencing. These results suggested that circRNAs were abundantly expressed in pancreatic islets, and various circRNA levels were dysregulated in diabetic mice models. Besides, the mRNA expression levels were compared, and the gene sets associated with cholesterol esterification were found to be the most significantly dysregulated (Fig. 1D, E and F). This suggested that cholesterol esterification might be important for $\beta$-cell functions under diabetic condition. However, the function of dysregulated circRNAs in $\beta$ cells

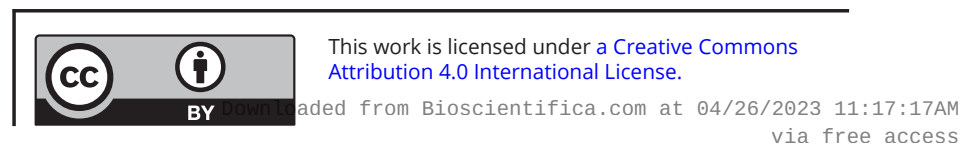




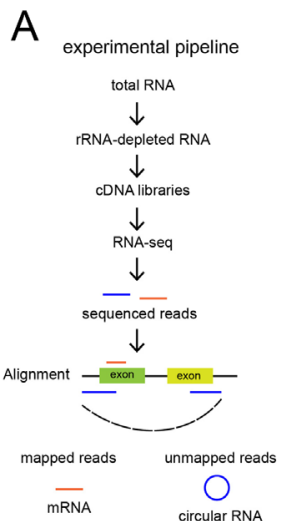

B

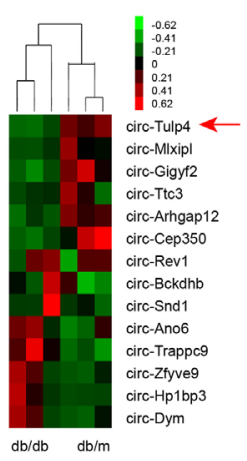

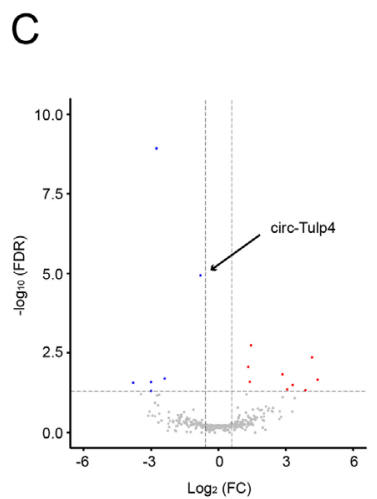

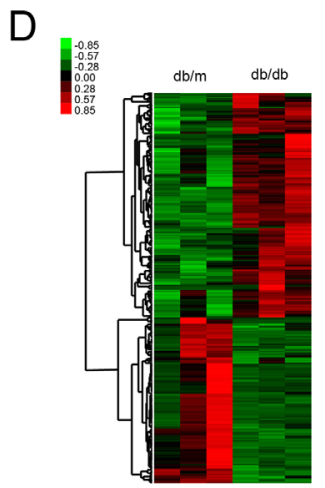

$E$

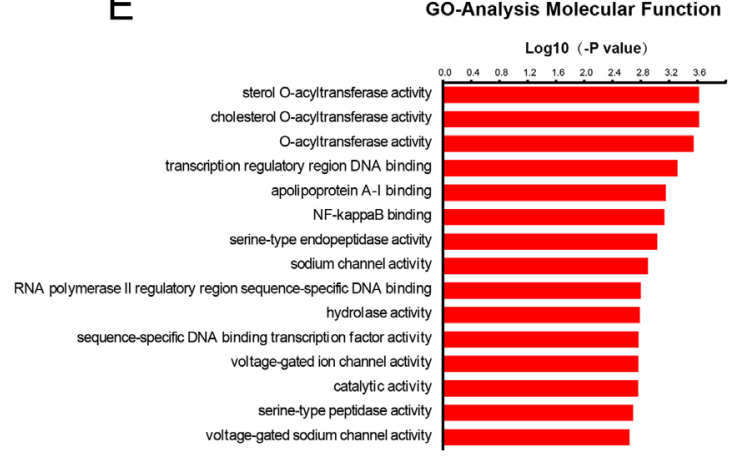

$\mathrm{F}$

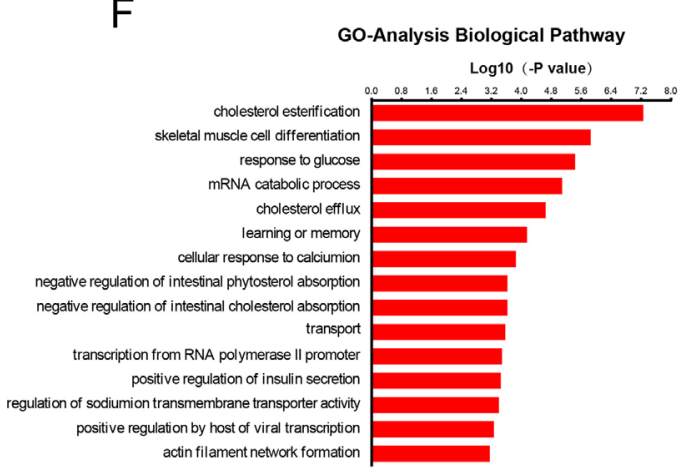

Figure 1

RNA-seq analysis of circRNA and mRNA expression patterns in islets of three $\mathrm{db} / \mathrm{db}$ and three $\mathrm{db} / \mathrm{m}$ mice. (A) RNA-seq experiment pipeline. (B) Clustered heat map of the differentially expressed circRNAs with a fold change of more than 1.5, which displayed on a scale from green (low) to red (high). (C) Volcano plot showing circular RNA $\log _{2}$ fold changes (FC) (on the X-axis) and the corresponding tempered $\log _{10}$ FDR values (on the Y-axis). (D) Profile of upregulated and downregulated mRNAs. Green indicated low expression and red high expression. The top 15 involved molecular functions (E) and biological pathways (F) in dysregulated mRNAs analyzed by gene ontology (GO).

A

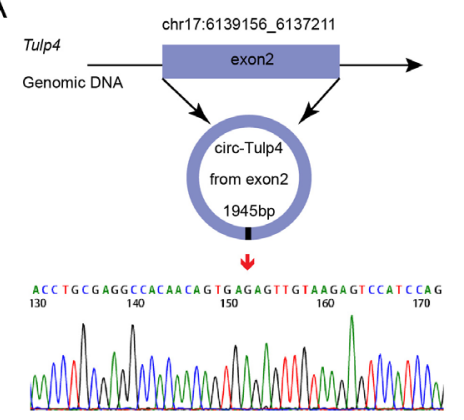

$\mathrm{D}$

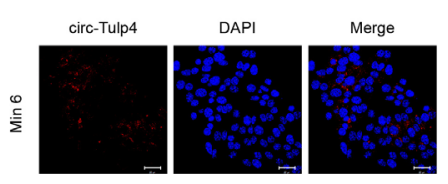

B

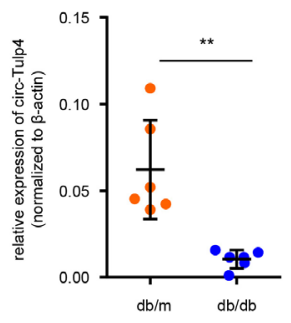

E

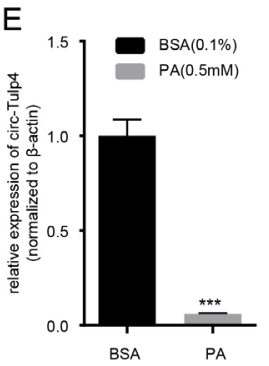

C
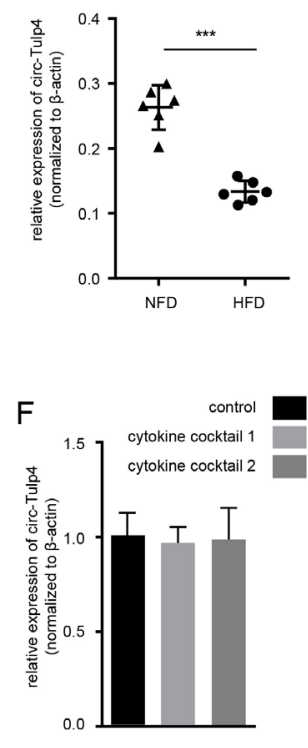

Figure 2

Expression of circ-Tulp4 decreased in islets of $\mathrm{db} / \mathrm{db}$ mice and Min6 cells exposed to PA. (A) Schematic representation of circ-Tulp4 formation; the splice junction sequence was Sanger sequenced using cDNA samples from PCR. Expression level of circ-Tulp4 was detected by qRT-PCR in islets of $\mathrm{db} / \mathrm{db}$ and $\mathrm{db} / \mathrm{m}$ mice (B), or in C57BL/6] mice on a normal control (NFD) or high-fat diet (HFD) (C) ( $n=6$, respectively). $* \star P<0.01 ; * * * P<0.001$ vs indicated groups. $\beta$-actin served as an internal control. (D) In situ hybridization (FISH) was used to determine the localization of circ-Tulp4 in Min6 cells. Expression level of circ-Tulp4 in Min6 cells exposed to PA (E) or cytokine cocktails (F). ${ }^{* * *} P<0.001$ vs the control group. The concentration of cytokine cocktails was depicted in detail in the Supplementary Materials and methods (see section on supplementary materials given at the end of this article) in detail. https://jme.bioscientifica.com https://doi.org/10.1530/JME-20-0079 (c) 2020 The authors Published by Bioscientifica Ltd. Printed in Great Britain
This work is licensed under a Creative Commons Attribution 4.0 International License. 
and its relationship with cholesterol esterification-related genes remained unknown.

\section{Circ-Tulp4 was highly expressed in mice pancreatic islets and affected by the lipotoxic condition}

Next, circ-Tulp4 was chosen for its displaying the largest number of reads in Supplementary Table 2, with 150.87 normalized reads and the expression decreased by 1.76 fold in the $\mathrm{db} / \mathrm{db}$ mice. The genomic structure of circ-Tulp4 was shown in Fig. 2A; it comprised an exonic sequence of 1945 bp with high conservation across species (using MUSCLE tools shown in the Supplementary Materials and methods). We confirmed that levels of circ-Tulp4 were decreased in islets of $\mathrm{db} / \mathrm{db}$ mice and HFD C57BL/6J mice
(Fig. 2B and C). Localization in $\beta$ cells was evaluated by in situ hybridization with probes covering the junction site of circ-Tulp4 (Fig. 2D).

The expression level in $\beta$ cells exposed to elevated concentrations of non-esterified fatty acid (NEFA) was tested to determine whether lipotoxic condition contributed to the expression changes of circ-Tulp4 detected in diabetic mice. The exposure of Min6 cells to palmitate acid (PA) $(0.5 \mathrm{mM})$ resulted in significantly lower expression levels of circ-Tulp4 (Fig. 2E). However, the circ-Tulp4 level was not significantly affected in Min6 cells treated with diabetes-associated cytokine cocktails (Fig. 2F). Thus, the analysis revealed that circTulp4 was regulated by NEFA in Min6 cells, suggesting that the low expression of circ-Tulp4 might be related to $\beta$-cell lipotoxicity and the development of T2DM.
A

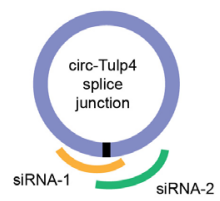

$\mathrm{D}$

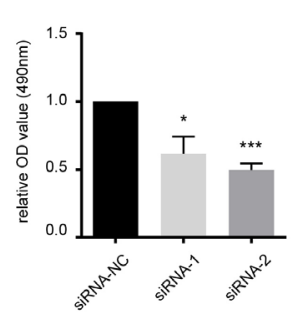

G
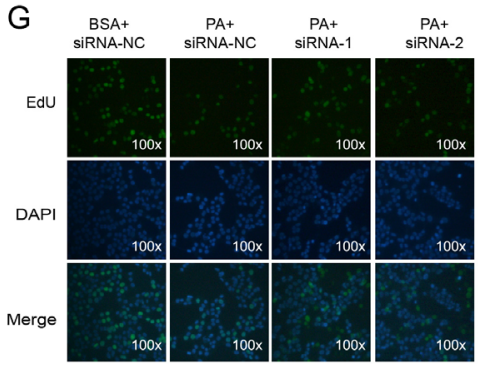

E
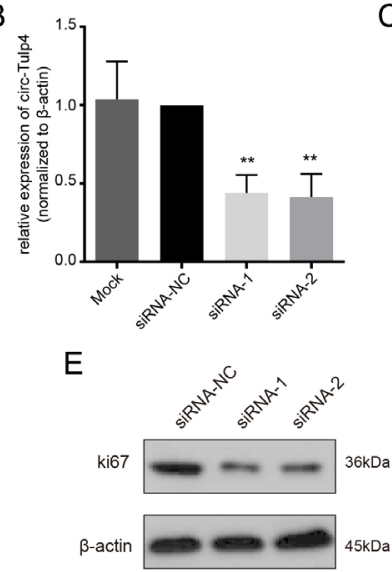

C

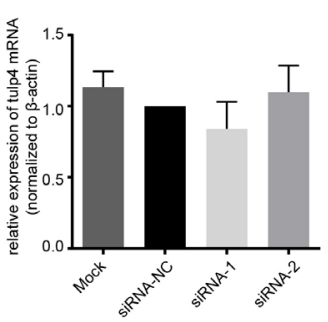

$\mathrm{F}$

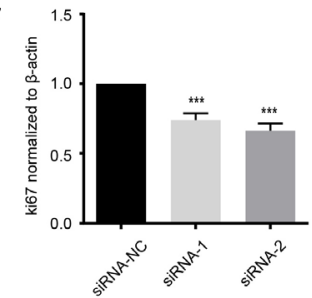

$\mathrm{H}$
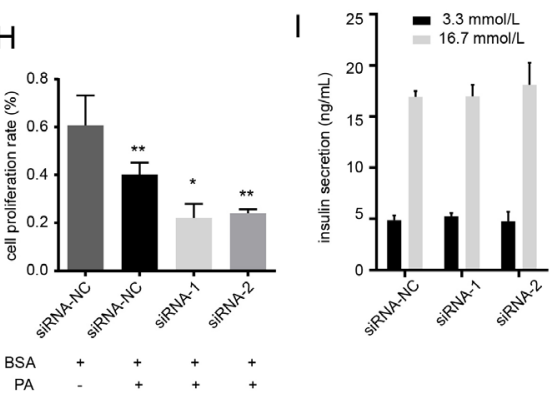

$\mathrm{K}$

$J$

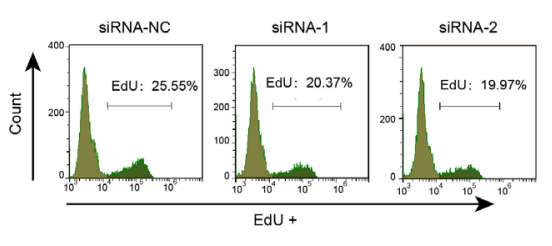

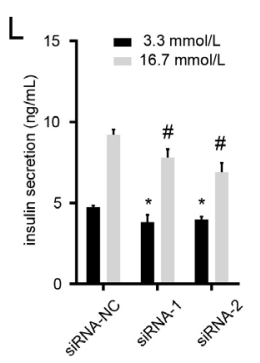

Figure 3

Downregulation of circ-Tulp4 inhibited $\beta$-cell function in the presence of PA. (A) Schematic representation of designed siRNAs for circ-Tulp4 at splice junction. Expression of circ-Tulp4 (B) and tulp4 mRNA (C) were detected by qRT-PCR in siRNA-1, siRNA-2, or mock-transfected Min6 cells. (D) The Min6 cells were transfected with circ-Tulp4 siRNA-1 or siRNA-2 for $48 \mathrm{~h}$, followed by PA $(0.5 \mathrm{mM})$ treatment for $24 \mathrm{~h}$. Cell proliferation ability was detected by MTS. Western blot assays were used to analyze the expression level of ki67 in transfected cells ( $E$ and F). To assess the cell proliferation rate, EdU incorporation was detected by microscope ( $\mathrm{G}$ and $\mathrm{H}$ ) or flow cytometry $(\mathrm{V}$ and K). Insulin secretion levels of Min6 cells after BSA (I) or PA (L) treatment were analyzed using GSIS assay. Green: EdU-positive staining. Blue: Hoechst 33342 staining of the nuclei. $* P<0.05 ; * * P<0.01$; $* * * P<0.001$ vs siRNA-NC transfected cells, or solvent (BSA) treated cells, or siRNA-NC transfected cells in $3.3 \mathrm{mmol} / \mathrm{L}$ glucose. $\# \mathrm{P}<0.05$ vs siRNA-NC transfected cells in $16.7 \mathrm{mmol} / \mathrm{L}$ glucose. https://jme.bioscientifica.com https://doi.org/10.1530/JME-20-0079 (c) 2020 The authors Published by Bioscientifica Ltd. Printed in Great Britain

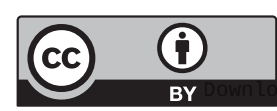

This work is licensed under a Creative Commons Attribution 4.0 International License. 


\section{Circ-Tulp4 maintained $\beta$-cell function under lipotoxic conditions}

Circ-Tulp4 expression was modulated to establish the biological role in $\beta$ cells. Two siRNAs or a negative control sequence (siRNA-NC) was transiently transfected into Min6 cells, and the effect of siRNA-mediated knockdown of circ-Tulp4 was assessed after $48 \mathrm{~h}$. As expected, the treatment effectively silenced the circular transcripts for approximately $50 \%$ reduction, whereas it did not affect the expression of linear mRNAs (Fig. 3A, B and C). A subsequent MTS assay showed that cell survival significantly reduced in the circ-Tulp4 siRNA-treated group under lipotoxic condition, whereas no obvious difference was observed by downregulating circ-Tulp4 alone (Fig. 3D and Supplementary Fig. 2A, B, C). The cell proliferation rate consistently diminished by EdU assays (Fig. 3G, H, J, $\mathrm{K}$ and Supplementary Fig. 2D, E); so was the proliferationrelated protein level of ki67 (Fig. 3E, F and Supplementary
Fig. 2F). Additionally, defective GSIS was observed after knocking down circ-Tulp4 under lipotoxic condition (Fig. 3I and L). In contrast, circ-Tulp4 silencing did not affect the apoptosis of Min6 cells (Supplementary Fig. 2I and L) or alter insulin biosynthesis (Supplementary Fig. 2G and $\mathrm{H})$. Hence, the silencing of circ-Tulp4 negatively affected the $\beta$-cell function.

Next, whether the upregulation of circ-Tulp4 level affected $\beta$-cell function was also investigated. AAV vector overexpressing circ-Tulp4 could efficiently produce a circular transcript partly resistant to RNase R digestion (Fig. 4A, B and C). As shown in Fig. 4D and E, PA inhibition of cell survival significantly decreased in Min6 cells with overexpression of circ-Tulp4. These effects were further confirmed with increased cell proliferation rate, as shown in the EdU assays (Fig. 4G and I) and increased protein level of ki67 (Fig. 4F). Additionally, though no obvious change in the mRNA levels of insulin1 (ins1) or insulin2 (ins2) was observed, insulin secretion was notably improved after
A

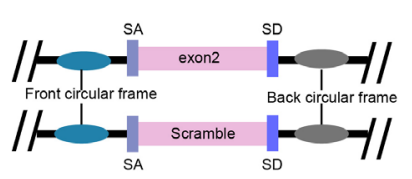

B

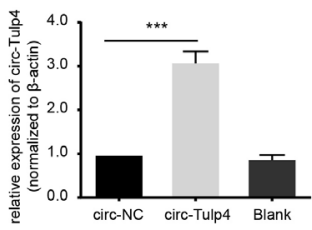

C

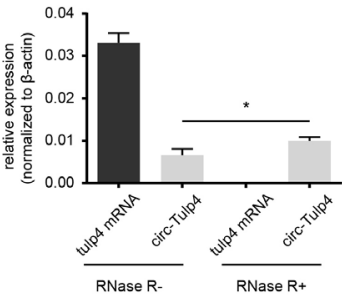

D

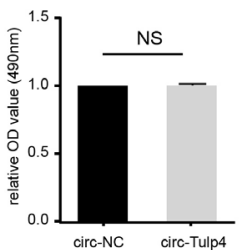

E

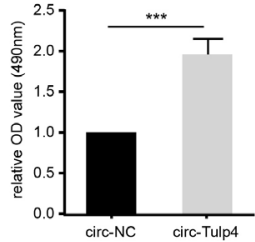

G
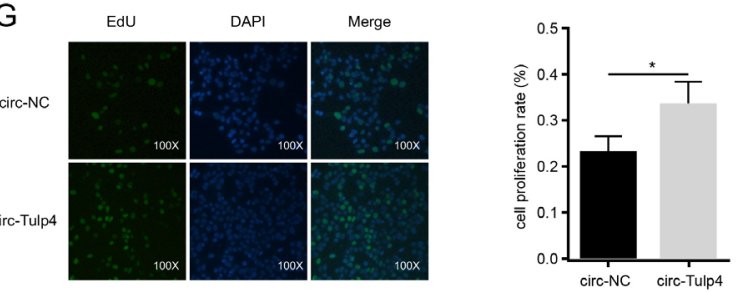

$\mathrm{H}$

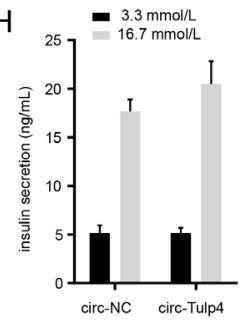

।

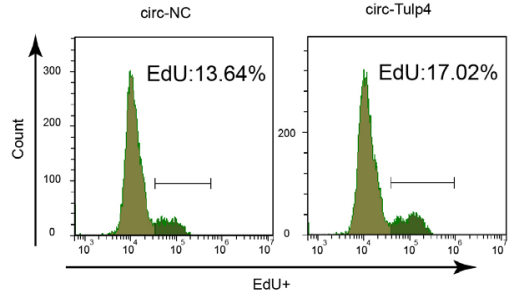

$\mathrm{F}$

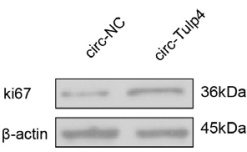

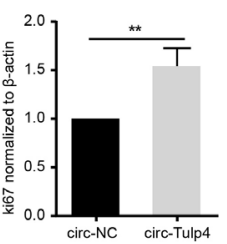

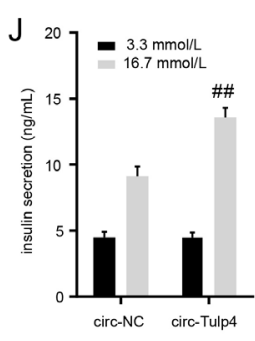

Figure 4

Upregulation of circ-Tulp4 alleviates $\beta$-cell dysfunction in the presence of PA. (A) Schematic representation of circ-Tulp4 and NC AAV vector construction. Expression of circ-Tulp4 and tulp4 mRNA was measured by qRT-PCR in the circ-Tulp4 or NC vector-infected Min6 cells (B), with or without RNase R treatment (C). Min6 cells were infected with indicated AAV vectors for $48 \mathrm{~h}$, followed by BSA (D) or PA (E) treatment for $24 \mathrm{~h}$. Cell proliferation ability was detected by MTS. (F) Western blot assays were used to analyze the protein expression level of ki67. To assess the cell proliferation rate, EdU incorporation was detected using a microscope (G) or flow cytometry (I). GSIS assay was used to detect insulin secretion of Min6 cells after BSA $(\mathrm{H})$ or PA $(\mathrm{J})$ treatment. Green: EdU-positive staining. Blue: Hoechst 33342 staining of the nuclei. ${ }^{\star} P<0.05$; $* \star P<0.01$; $\star \star \star P<0.001$ vs NC vector infected cells. $\# P<0.01$ vs NC vector infected cells in $16.7 \mathrm{mmol} / \mathrm{L}$ glucose.

https://jme.bioscientifica.com https://doi.org/10.1530/JME-20-0079 (c) 2020 The authors Published by Bioscientifica Ltd. Printed in Great Britain
This work is licensed under a Creative Commons Attribution 4.0 International License. 
overexpressing circ-Tulp4 (Fig. 4H, J and Supplementary Fig. 3C). Also, apoptosis rate was unchanged with the overexpression of circ-Tulp4 (Supplementary Fig. 3A and B). In all, the overexpression of circ-Tulp4 alleviates $\beta$-cell dysfunction under lipotoxic condition.

Altogether, these results showed that circ-Tulp4 played a vital role in regulating $\beta$-cell function under the lipotoxic environment, which may be a potential target in treating T2DM.

\section{Bioinformatics identifies target genes affected by circ-Tulp4 changes}

As described in Fig. 1D and F, cholesterol esterification might play an important role in $\beta$-cell function under diabetic condition. The biological analysis data showed that the mRNA level of sterol O-acyltransferase 1 (soat1), a key enzyme gene in cholesterol esterification, was lower in diabetic mice islets $(P<0.05)$. The expression level of soat1 mRNA was tested to validate the bioinformatics analysis experimentally. The results showed that the expression of soat1 significantly decreased in the $\mathrm{db} / \mathrm{db}$ mice islets and HFD mice islets (Fig. $5 \mathrm{~A}$ and $\mathrm{B}$ ). In vitro, the expression of soat 1 consistently displayed significantly decreased levels under lipotoxic condition (Fig. 5C). These findings suggested that soat 1 might be related to $\beta$-cell dysfunction in the development of T2DM. Previous studies demonstrated that soat1 was needed for the cell proliferation and activation of adaptation to pathological concentrations of NEFA (Busch et al. 2005, Yue et al. 2014,
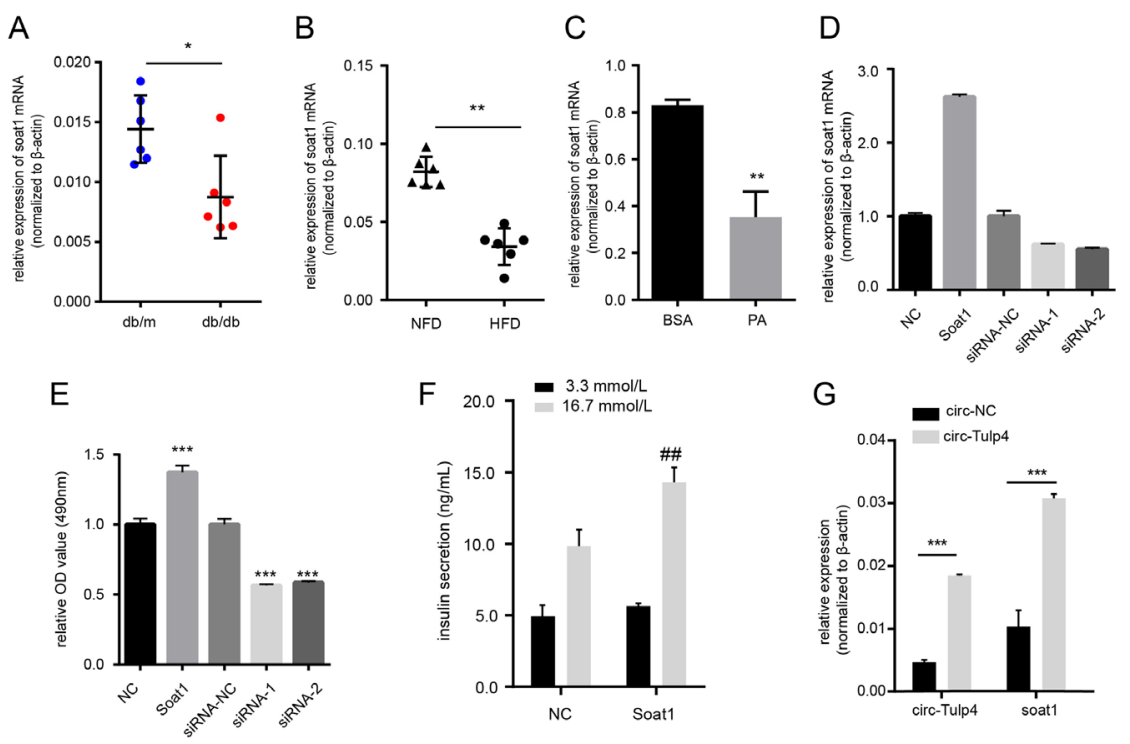
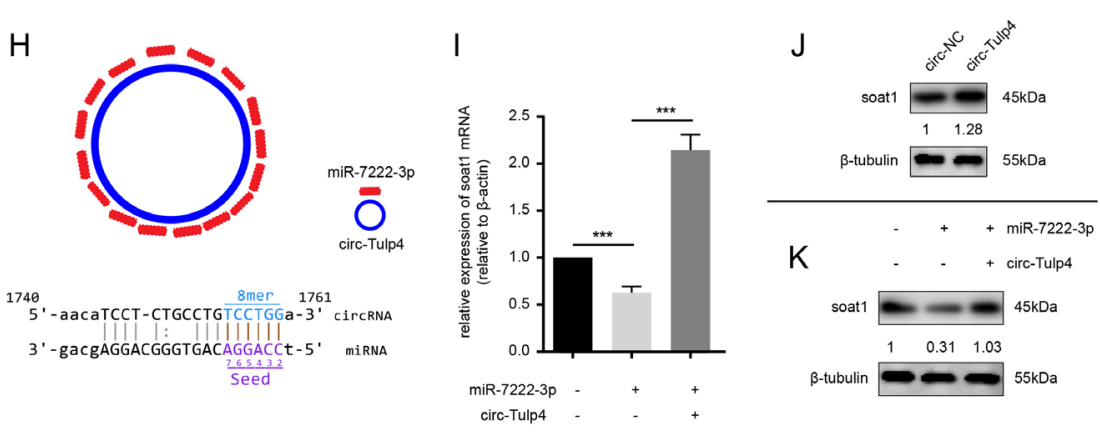

K

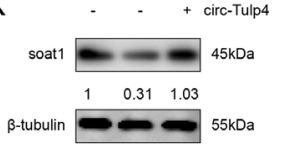

L

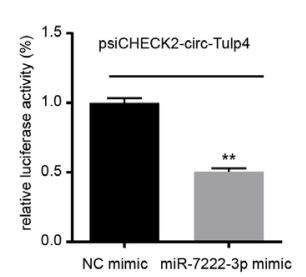

M
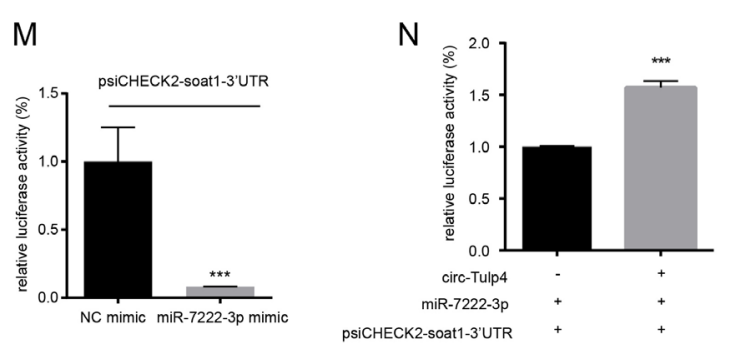

Figure 5

Expression of soat1 was downregulated in diabetic mice islets and Min6 cells exposed to PA, and it was regulated by circ-Tulp4 and miR-7222-3p. Expression level of soat1 in islets of $\mathrm{db} / \mathrm{db}$ and $\mathrm{db} / \mathrm{m}$ mice (A), or in C57BL/6J mice on a normal control (NFD) or high-fat diet (HFD) (B) ( $n=6$, respectively). ${ }^{*} P<0.05 ;{ }^{*} P<0.01$ vs indicated groups. $\beta$-actin served as an internal control. (C) Expression level of soat1 in Min6 cells exposed to PA. ${ }^{*} P P<0.01$ vs the solvent (BSA) control group. Soat1 was knocked down or overexpressed in Min6 cells, followed by PA (0.5 mM) treatment for $24 \mathrm{~h}$ (D). Cell proliferation ability was detected by MTS (E). Insulin secretion was detected by GSIS assay after overexpressing soat1. \# $P<0.01$ vs NC vector treated cells in $16.7 \mathrm{mmol} / \mathrm{L}$ glucose (F). Relative expression of circ-Tulp4 and soat1 mRNA after circ-Tulp4 or NC vector infection $(G)$. The 16 predicted binding sites for miR-7222-3p on circ-Tulp4 (H). Expression level of soat1 mRNA (I) or protein (K) in Min6 cells treated with either miR-7222-3p mimic or co-treated with miR-7222-3p mimic and circ-Tulp4 vector (I). Protein level of soat1 in Min6 cells after circ-Tulp4 vector infection (J). Dual-luciferase analysis in HEK293 cells after indicated treatment ( $L$ and $M)$. Competitive luciferase analysis in HEK293 cells $(\mathrm{N}) .{ }^{*} * P<0.01 ; * * * P<0.001$ vs the indicated groups. https://jme.bioscientifica.com https://doi.org/10.1530/JME-20-0079 (c) 2020 The authors Published by Bioscientifica Ltd. Printed in Great Britain

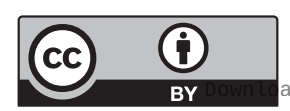

This work is licensed under a Creative Commons Attribution 4.0 International License. 
A

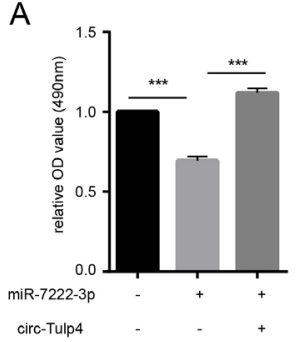

D

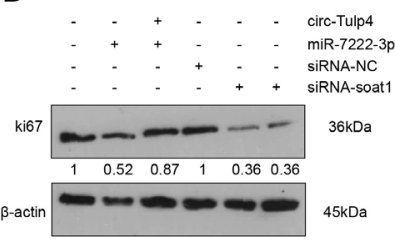

B

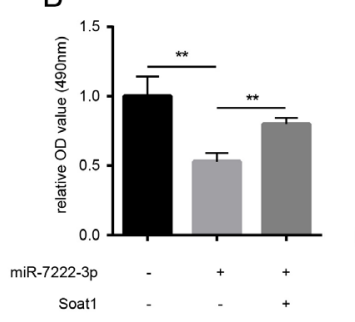

E

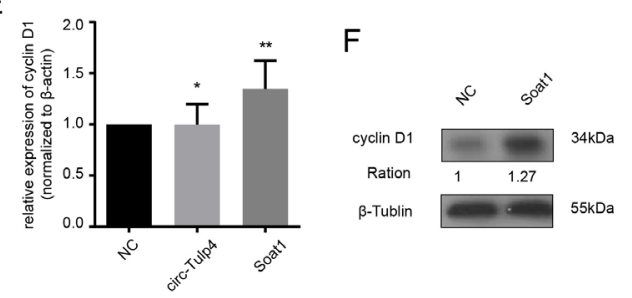

C

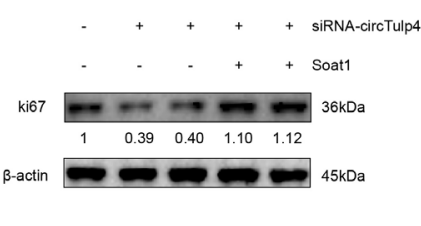

G

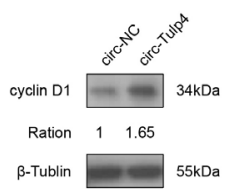

$\mathrm{H}$

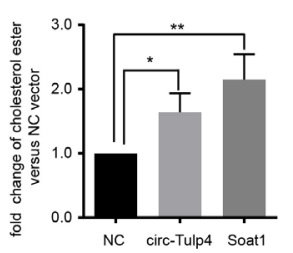

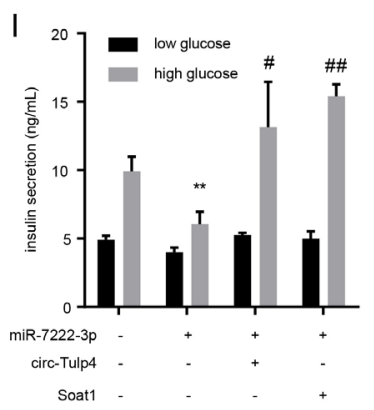

J

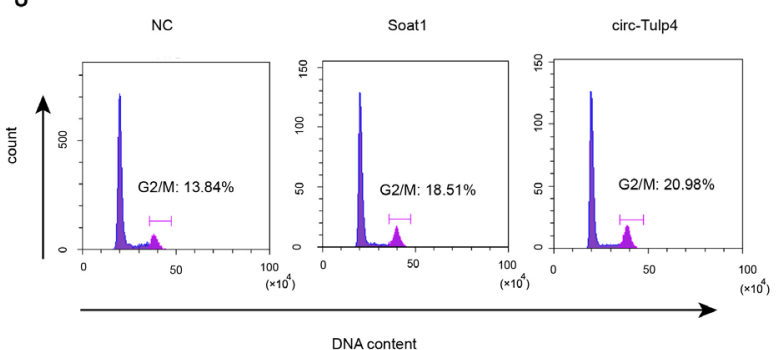

\section{Figure 6}

Upregulation of circ-Tulp4 affected the proliferation of $\beta$ cells by sponging miR-7222-3p and regulating soat1/cyclin D1 signaling. Min6 cells were transfected with miR-7222-3p mimic, or co-treated with circ-Tulp4 vector (A) or Soat1 vector (B) for $48 \mathrm{~h}$, followed by PA $(0.5 \mathrm{mM})$ treatment for $24 \mathrm{~h}$. Cell proliferation ability was detected by MTS. (C) Min6 cells were transfected with siRNA-1 or siRNA-2 for circ-Tulp4, or co-treated with Soat 1 vector for $48 \mathrm{~h}$, followed by PA (0.5 mM) treatment for $24 \mathrm{~h}$. Western blot assays were used to analyze the protein expression level of ki67. (D) Min6 cells were transfected with miR-7222-3p mimic, or co-treated with circ-Tulp4 vector for $48 \mathrm{~h}$, followed by PA ( $0.5 \mathrm{mM}$ ) treatment for $24 \mathrm{~h}$. Min6 cells were transfected with siRNA-1 or siRNA-2 for soat 1 for $48 \mathrm{~h}$, followed by PA $(0.5 \mathrm{mM})$ treatment for $24 \mathrm{~h}$. Protein expression of ki67 in indicated groups. The expression level of cyclin D1 mRNA (E) or cyclin D1 protein ( $F$ and $G$ ) in Min6 cells infected with circ-Tulp4 vector or Soat1 vector. Cell cholesterol easter content was examined after overexpressing circ-Tulp4 or Soat1 (H). GISI assay was performed to examine the insulin secretion of Min6 cells transfected with miR-7222-3p mimic, or co-treated with circ-Tulp4 vector or Soat1 vector (I). ${ }^{* * P}<0.01$ vs the NC treated group in $16.7 \mathrm{mmol} / \mathrm{L}$ glucose. ${ }^{*} P<0.05$; $\# P<0.01$ vs the miR-7222-3p mimic treated group in $16.7 \mathrm{mmol} / \mathrm{L}$ glucose. Cell cycle distribution was investigated by flow cytometry in Min6 cells infected with circ-Tulp4 vector or Soat1 vector (J). $* P<0.05 ; * \star P<0.01 ; * \star \star P<0.001$ vs the indicated groups.
Li et al. 2016, Stopsack et al. 2017). Hence, the next step was to test the hypothesis of whether soat 1 affected $\beta$-cell function and whether circ-Tulp4 regulated the expression of soat1.

Our previous data showed that silencing of soat1 impaired $\beta$-cell survival under lipotoxic condition, whereas the upregulation of soat1 had the opposite effect (Fig. 5E and Supplementary Fig. 3E, F). Protein level of ki67 was reduced after knocking down soat1 expression under lipotoxic condition (Fig. 6D and Supplementary Fig. 4E). Infecting Min6 cells with soat1 overexpression vector could elevated insulin secretion in $16.7 \mathrm{mmol} / \mathrm{L}$ glucose (Fig. 5F). Furthermore, the ectopic expression of circ-Tulp4 significantly promoted soat1 mRNA (Fig. 5G) and protein expression in Min6 cells (Fig. 5J). Hence, Printed in Great Britain soat1 was found to be related to $\beta$-cell dysfunction and post-transcriptionally modulated by circ-Tulp4. However, the mechanism remained to be further elucidated.

We postulated that circ-Tulp4 might act as a microRNA sponge to regulate the expression of soat1. To test this speculation, miRanda (http://www.microrna. org/microrna/home.do) and RNAhybrid (http://bibiserv. techfak.uni-bielefeld.de/rnahybrid/) were used to predict candidate miRNA, and miRNA with more than 10 potential binding sites on circ-Tulp4 were selected. Among these, only miR-7222-3p was able to reduce soat 1 mRNA (Fig. 5H and I) and protein (Fig. 5K) expression levels, and the effect could be rescued via co-overexpressing circTulp4 (Supplementary Fig. 3G, H and I). Next, to validate whether miR-7222-3p could interact with circ-Tulp4 and 
soat1 3'-UTR, a luciferase reporter assay was performed. The reporter construct and miR-7222-3p mimic or NC mimic were co-transfected into the HEK293 cells. The luciferase activity assay showed that miR-7222-3p bound to circ-Tulp4 and soat1 3'-UTR directly (Fig. 5L and M). Moreover, a competitive luciferase assay was performed to test the effect of circ-Tulp4 on miR-7222-3p activity. In the HEK293 cells, the overexpression of circ-Tulp4 blunted the negative effect of miR-7222-3p on the luciferase expression of luciferase reporter containing soat1 3'-UTR, whereas the NC construct did not (Fig. 5N). Taken together, these results demonstrated that circ-Tulp4 functioned as a miR-7222-3p sponge in $\beta$ cells.

Finally, whether the capacity of circ-Tulp4 to maintain $\beta$-cell function under NEFA-induced lipotoxicity depended on miR-7222-3p inhibition was investigated. The overexpression of miR-7222-3p receded cell proliferation, which was enhanced following the co-overexpression of circ-Tulp4 (Fig. 6A and D). As soat1 is the target gene of miR-7222-3p, the present study further revealed that the ectopic expression of miR-7222-3p inhibited the survival of Min6 cells, while the co-overexpression of soat1 re-enhanced cell survival (Fig. 6B). Cells with inhibited circ-Tulp4 expression showed lower ki67 protein levels compared with the control group; while the co-overexpression of soat1 recapitulated the effects of circ-Tulp4 activation (Fig. 6C). On the other hand, no significant differences in cell proliferation were observed under basal condition (Supplementary Fig. 4A, $B, C$ and D). Insulin secretion was significantly decreased after ectopic expression of miR-7222-3p, while improved following the co-expression of circ-Tulp4 or soat1 (Fig. 6I). Besides, the ectopic expression of miR-7222-3p did not affect cell apoptosis either in basal or lipotoxic condition, and co-overexpression of miR-7222-3p and circ-Tulp4 or soat1 also displayed negative results (Supplementary Fig. 4I). These data suggested that the effect of circ-Tulp4 on $\beta$-cell function related to an increased expression of soat1 through the inhibition of miR-7222-3p activity under lipotoxic condition.

\section{Soat1 enhanced cell proliferation through cyclin D1 activation}

This study demonstrated that miR-7222-3p suppressed cell survival in the presence of PA, and the upregulation of circ-Tulp4 and soat 1 rescued miR-7222-3p inhibition on cell survival. Previous studies indicated that cyclin D1, which positively regulated the cell cycle, was a potential soat1 target (Batetta et al. 2003). However, the effect of soat1 upregulation on the cell cycle was still not verified in $\beta$ cells. As revealed by qRT-PCR and western blot analysis, cyclin D1 mRNA (Fig. 6E) and protein expression levels (Fig. 6F) were modified by the upregulation of soat 1 . As soat 1 was post-transcriptionally regulated by circ-Tulp4, the expression level of cyclin D1 was also increased on the overexpression of circ-Tulp4 (Fig. 6G and $\mathrm{H})$. Under the basal condition, the expression of cyclin D1 was unchanged upon upregulation of circ-Tulp4 or soat1 (Supplementary Fig. 4F, G and H). As shown by flow cytometry assays (Fig. 6J), the increased expression of soat1 displayed beneficial effects on $\beta$-cell proliferation, and the overexpression of circ-Tulp4 also increased the percentage of cells in the $\mathrm{G} 2 / \mathrm{M}$ phase of the cell cycle, promoting proliferation. The level of cholesterol ester, the product of soat1 catalyzation, was also increased upon upregulation of circ-Tulp4 or soat1 in Min6 cells (Fig. $6 \mathrm{H})$. Hence, the translational upregulation of soat 1 and cyclin D1 could explain the phenotypic traits of $\beta$ cells overexpressing circ-Tulp4.

\section{Discussion}

$\beta$-Cell lipotoxicity and progressive dysfunction are predisposing factors for T2DM. Chronic exposure to elevated NEFA is detrimental for $\beta$ cells, resulting in reduced proliferation and increased apoptosis. A persistent imbalance between excessive $\beta$-cell apoptosis and restricted proliferation leads to $\beta$-cell mass loss and reduced insulin secretion (Biden et al. 2014). Thus, controlling lipidderived $\beta$-cell adaptive transitions is indispensable for maintaining glucose homeostasis. Notwithstanding its importance, $\beta$-cell adaptive regulatory networks and molecular mechanisms are still undefined, particularly for circRNAs. This study proved that the high abundance of circ-Tulp4 in $\beta$ cells inhibited miR-7222-3p mediated suppression of soat1 expression, reinforcing cyclin D1 expression and cell cycle progression, and alleviating $\beta$-cell dysfunction under lipotoxic condition.

Recently, a large number of circRNAs have been revealed with novel bioinformatic approaches and been detected in mammalian cells. Nevertheless, only a handful of them is functionally characterized. In this study, more than 5000 circRNAs were detected using RNA sequencing, indicating that circular transcripts were abundant in islets. Among these, 346 displayed dysregulated expression in diabetic mice, and 14 previously annotated circRNAs displayed different expression patterns with more than 1.5-fold change. A similar expression pattern in circ-Arhgap12 was also observed by Stoll et al. (2018)

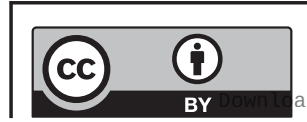

This work is licensed under a Creative Commons Attribution 4.0 International License. ded from Bioscientifica.com at 04/26/2023 11:17:17AM 
previously, analyzing diabetic mice islets circRNAs expression by microarray. Besides, we found that silencing circ-Arhgap12 didn't affect $\beta$-cell proliferation, which was consistent with Stoll's study (data was not shown) (Stoll et al. 2018). In this study, circ-Tulp4 was selected for its upmost number of reads among candidate circRNAs. Both the human circ-Tulp4 and mouse circ-Tulp4 were transcribed from the second exon of TUB like protein 4 (TULP4) gene. The sequences of circ-Tulp4 were well conserved between mouse and human, and it was also found expressed in mouse brain (Supplementary Materials and methods) (Rybak-Wolf et al. 2015). However, the functional role was not tested before. Here, we found that circ-Tulp4 expression was reduced in diabetic mice islets and Min6 cells exposed to NEFA, reflecting an important role in the regulation of $\beta$-cell function. Additionally, we tested the second significantly downregulated gene of circMlxipl. We found that it was also regulated by NEFA (data in submission). The functional role of other differentially expressed circRNAs might affect proliferation, apoptosis, or insulin secretion; however, it remained to be defined.

Previous studies explore the involvement of circRNAs in cell proliferation through various molecular mechanisms (Rybak-Wolf et al. 2015). For example, circHIPK3 promoted proliferation of human tumor cells by binding with multiple miRNA, and a research team showed that circ-SHPRH, circ-FBXW7, and circ-PINT suppressed human glioblastoma growth through direct protein translation (Zheng et al. 2016, Yang et al. 2018, Zhang et al. 2018a). The studies by Du et al. (2016) showed that circFoxo3 might bind and sequester cell cycle-related proteins outside the nucleus to inhibit cell proliferation. Our study demonstrated a new pathway regarding the positive association between cell proliferation and circ-Tulp4 in $\beta$ cells, which interacted and modulated the activity of miR-7222-3p. Besides, increased insulin secretion was also observed upon overexpression of circTulp4. These data collectively illustrated that circ-Tulp4 was significant in regulating $\beta$-cell function, which might be developed as a therapeutic target for T2DM.

Increasing evidence suggested that the function of circRNA is associated with its subcellular compartmentalization. Considering the enrichment of circ-Tulp4 in the cytoplasm, it was speculated that it might act as a sponge by sequestering miRNA to promote the translation of soat1 mRNA. Using bioinformatic approaches, circ-Tulp4 was predicted to target numerous miRNA. Among these, only miR-7222-3p was found to have an impact on the expression of soat1. Previously, miR-7222-3p was found expressed in mouse liver tissues (http://mirtarbase.mbc.nctu.edu.tw/) (Luna et al. 2017). Here, we found that miR-7222-3p was enriched in Min6 cells. Besides, since the human circ-Tulp4 was also comprised of exon, we hypothesized that it might also locate in the cytoplasm and could reserve $\beta$-cell function through targeting micro RNA. But due to the limited information regarding human $\beta$-cell mircoRNA expression (Cebola \& Pasquali 2016), the detailed mechanism needs to be further detected. In our study, we found that miR-7222-3p could directly target circ-Tulp4 and repress expression of cholesterol esterification-related gene soat1. So far, these results highlighted some important mechanisms leading to lipotoxicity in $\beta$ cells with reduced level of circ-Tulp4.

It is reported that the effect of specific fatty acids on $\beta$ cells is directly related to the degree of their saturation (Janikiewicz et al. 2015, Liu et al. 2019). According to the Prospective Metabolism and Islet Cell Evaluation (PROMISE) survey, an impaired $\beta$-cell function and a higher risk of T2DM were correlated with the serum saturate lipid levels (Johnston et al. 2016). Besides, chronic exposure of $\beta$ cells to unsaturated fatty acids significantly increases $\beta$-cell survival (Liu et al. 2019). Additionally, Busch et al. (2005) reported that the level of stearoyl-CoA desaturase $(S C D)$, an important gene in the regulation of cholesterol unsaturation, was increased in PA-resistant Min6 cells. The inhibition of SCD reduced $\beta$-cell survival under lipotoxic condition. In the present study, gene sets involved in the regulation of cholesterol esterification, a key procedure in cholesterol unsaturation, were the most significantly dysregulated. Moreover, the level of soat1, a key enzyme during cholesterol esterification, was significantly lower in the diabetic mice islets and Min6 cells in the presence of PA. Given these findings, we hypothesized that $\beta$-cell failure due to chronic exposure to NEFA could be linked to decreased desaturation of fatty acids, which was achieved by cholesterol esterification.

Exogenous cholesterol spillover has two categories inside cells: cholesterol derivatives such as secondary messengers and toxic fatty acids (Chang et al. 2006). Increasing intracellular saturated fatty acids accumulation aggressively impair cell survival, inducing chronic toxicity to cells. Once exogenous cholesterol is incorporated into cholesterol ester (CE), the cells could take advantage of the esterified form to avoid the toxicity of excess saturated cholesterol. Indeed, CE is found to be a strong proliferative factor for cells, including cancer cells, stem cells, and retinal cells (Yue et al. 2014, Lee et al. 2015, Geng et al. 2016, Li et al. 2016). CE depletion by abrogating soat1 activity significantly hinders cell growth due to the 
elevation of saturated cholesterol levels (Buhman et al. 2000, Busch et al. 2005, Kedi et al. 2009, Li et al. 2016). Additionally, CE synthesis is essential for adaptation to increased cholesterol metabolic needs and intracellular cholesterol homeostasis (Busch et al. 2005, Lee et al. 2015). A general decrease in cholesterol esterification, particularly concerning the toxic PA, could impair the function and survival of $\beta$ cells (Busch et al. 2005).

The terminal step of CE synthesis is soat1 catalyzation. Soat 1 is ubiquitously expressed in tissues and highly conserved among mammals (Chang et al. 2006). The mRNA expression of soat1 is transcriptionally regulated through mechanisms involving extracellular cholesterol overloading and increasing metabolic demands. As mentioned earlier, the overexpression of soat1 promotes cell proliferation, and vice versa (Yue et al. 2014, Geng et al. 2016, Li et al. 2016, Stopsack et al. 2017), which might be associated with increasing cyclin D1 expression (Batetta et al. 2003). The overexpression of soat1 enhances 7-ketocholesterol (7KCh)-fatty acid ester formation from toxic $7 \mathrm{KCh}$, which significantly protects cells from 7KCh-induced cell death (Lee et al. 2015). Our study also proved that the soat1 enhanced $\beta$-cell proliferation under PA-induced toxic condition, possibly through regulating cyclin D1 expression. Moreover, the impairment in insulin secretion was improved by upregulating soat 1 expression. These findings imply that soat1 plays a key role in the adaptation to saturate fatty acids-induced cell impairment through various mechanisms.

Recently, soat1 is assumed to be a target for developing anti-atherosclerotic drugs. But neither overall

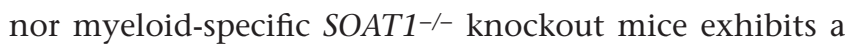
hyperglycemic condition (Lee et al. 2015). The reason might be correlated with the complex interactions of various systems in mice models. To understand the functional role of soat 1 in $\beta$ cells, $\beta$-cell-specific SOAT1-/knockout mice is needed for further study. Besides, it is proposed that soat1 inhibitor could be used for developing anti-tumor drugs. The negative effect of soat1 inhibitors on pancreatic $\beta$ cells should be noted, especially for patients with hyperlipidemia (Cheng et al. 2018). In diabetic mice, soat1 was significantly downregulated in islets. In vitro, it was proved that the expression of soat 1 was epigenetically regulated by circ-Tulp4 and miR-7222-3p. Besides, CE content was increased in Min6 cells upon upregulation of soat1 or circ-Tulp4. Nevertheless, little is known about the mechanisms that trigger the transition of unsaturated fatty acids in $\beta$ cells, and whether inhibition of CE storage or synthesis has negative effects on $\beta$-cell proliferation needs further confirmation.
Our study improved the understanding of the role of cholesterol esterification in $\beta$ cells and opened opportunities for treating $\beta$-cell lipotoxic impairment. We confirmed that NEFA-induced $\beta$-cell impairment triggered the downregulation of circ-Tulp4, and circTulp4 promoted cell function by inducing the expression of soat 1 through the inhibition of miR-7222-3p. These results suggested that the upregulation of circ-Tulp4 might be a potential therapeutic intervention for T2DM. Besides, soat1 might be important for maintaining $\beta$-cell function under lipotoxic condition.

Supplementary materials

This is linked to the online version of the paper at https://doi.org/10.1530/ JME-20-0079.

\section{Declaration of interest}

The authors declare that there is no conflict of interest that could be perceived as prejudicing the impartiality of the research reported.

\section{Funding}

This work was supported by the Department of Finance of Guangdong Province (Grant number: 20160902).

\section{Data availability statement}

The data used to support the findings of this study are available from the corresponding authors on reasonable request.

\section{Acknowledgement}

The authors warmly thank Dr Jie Chen for expert technical assistance.

\section{References}

Anders S \& Huber W 2010 Differential expression analysis for sequence count data. Genome Biology 11 R106. (https://doi.org/10.1186/ gb-2010-11-10-r106)

Ashburner M, Ball CA, Blake JA, Botstein D, Butler H, Cherry JM, Davis AP, Dolinski K, Dwight SS, Eppig JT, et al. 2000 Gene ontology: tool for the unification of biology. The Gene Ontology Consortium. Nature Genetics 25 25-29. (https://doi.org/10.1038/75556)

Barrett SP, Wang PL \& Salzman J 2015 Circular RNA biogenesis can proceed through an exon-containing lariat precursor. eLife 4 e07540. (https://doi.org/10.7554/eLife.07540)

Batetta B, Mulas MF, Sanna F, Putzolu M, Bonatesta RR, GasperiCampani A, Roncuzzi L, Baiocchi D \& Dessì S 2003 Role of cholesterol ester pathway in the control of cell cycle in human aortic smooth muscle cells. FASEB Journal 17 746-748. (https://doi. org/10.1096/fj.02-0396fje)

Biden TJ, Boslem E, Chu KY \& Sue N 2014 Lipotoxic endoplasmic reticulum stress, $\beta$ cell failure, and type 2 diabetes mellitus. Trends in Endocrinology and Metabolism 25 389-398. (https://doi.org/10.1016/j. tem.2014.02.003)

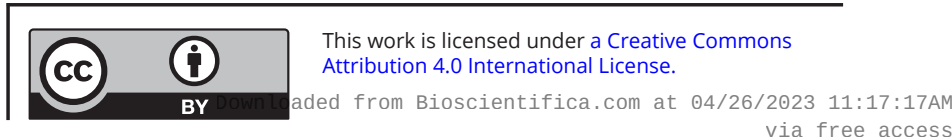


Buhman KF, Accad M \& Farese RV 2000 Mammalian acylCoA:cholesterol acyltransferases. Biochimica et Biophysica Acta 1529 142-154. (https://doi.org/10.1016/s1388-1981(00)00144-x)

Busch AK, Gurisik E, Cordery DV, Sudlow M, Denyer GS, Laybutt DR, Hughes WE \& Biden TJ 2005 Increased fatty acid desaturation and enhanced expression of stearoyl coenzyme A desaturase protects pancreatic beta-cells from lipoapoptosis. Diabetes 54 2917-2924. (https://doi.org/10.2337/diabetes.54.10.2917)

Cebola I \& Pasquali L 2016 Non-coding genome functions in diabetes. Journal of Molecular Endocrinology 56 R1-R20. (https://doi. org/10.1530/JME-15-0197)

Chang TY, Chang CCY, Ohgami N \& Yamauchi Y 2006 Cholesterol sensing, trafficking, and esterification. Annual Review of Cell and Developmental Biology 22 129-157. (https://doi.org/10.1146/annurev. cellbio.22.010305.104656)

Cheng C, Geng F, Cheng X \& Guo D 2018 Lipid metabolism reprogramming and its potential targets in cancer. Cancer Communications 38 27. (https://doi.org/10.1186/s40880-018-0301-4)

Draghici S, Khatri P, Tarca AL, Amin K, Done A, Voichita C, Georgescu C \& Romero R 2007 A systems biology approach for pathway level analysis. Genome Research 17 1537-1545. (https://doi.org/10.1101/ gr.6202607)

Du WW, Yang W, Liu E, Yang Z, Dhaliwal P \& Yang BB 2016 Foxo3 circular RNA retards cell cycle progression via forming ternary complexes with p21 and CDK2. Nucleic Acids Research 44 2846-2858. (https://doi.org/10.1093/nar/gkw027)

Du WW, Yang W, Chen Y, Wu ZK, Foster FS, Yang Z, Li X \& Yang BB 2017 Foxo3 circular RNA promotes cardiac senescence by modulating multiple factors associated with stress and senescence responses. European Heart Journal 38 1402-1412. (https://doi. org/10.1093/eurheartj/ehw001)

Enuka Y, Lauriola M, Feldman ME, Sas-Chen A, Ulitsky I \& Yarden Y 2016 Circular RNAs are long-lived and display only minimal early alterations in response to a growth factor. Nucleic Acids Research $\mathbf{4 4}$ 1370-1383. (https://doi.org/10.1093/nar/gkv1367)

Ferrannini E \& Mari A 2004 Beta cell function and its relation to insulin action in humans: a critical appraisal. Diabetologia 47 943-956. (https://doi.org/10.1007/s00125-004-1381-z)

Friedman RC, Farh KK, Burge CB \& Bartel DP 2009 Most mammalian mRNAs are conserved targets of microRNAs. Genome Research 19 92-105. (https://doi.org/10.1101/gr.082701.108)

Garcia DM, Baek D, Shin C, Bell GW, Grimson A \& Bartel DP 2011 Weak seed-pairing stability and high target-site abundance decrease the proficiency of lsy-6 and other microRNAs. Nature Structural and Molecular Biology 18 1139-1146. (https://doi.org/10.1038/nsmb.2115)

Geng F, Cheng X, Wu X, Yoo JY, Cheng C, Guo JY, Mo X, Ru P, Hurwitz B, Kim SH, et al. 2016 Inhibition of SOAT1 suppresses glioblastoma growth via blocking SREBP-1-mediated lipogenesis. Clinical Cancer Research 22 5337-5348. (https://doi. org/10.1158/1078-0432.CCR-15-2973)

Grimson A, Farh KK, Johnston WK, Garrett-Engele P, Lim LP \& Bartel DP 2007 MicroRNA targeting specificity in mammals: determinants beyond seed pairing. Molecular Cell 27 91-105. (https://doi. org/10.1016/j.molcel.2007.06.017)

Guay C, Jacovetti C, Nesca V, Motterle A, Tugay K \& Regazzi R 2012 Emerging roles of non-coding RNAs in pancreatic $\beta$-cell function and dysfunction. Diabetes, Obesity and Metabolism 14 (Supplement 3) 12-21. (https://doi.org/10.1111/j.1463-1326.2012.01654.x)

Heit JJ, Karnik SK \& Kim SK 2006 Intrinsic regulators of pancreatic betacell proliferation. Annual Review of Cell and Developmental Biology 22 311-338. (https://doi.org/10.1146/annurev.cellbio.22.010305.104425)

Janikiewicz J, Hanzelka K, Kozinski K, Kolczynska K \& Dobrzyn A 2015 Islet $\beta$-cell failure in type 2 diabetes - within the network of toxic lipids. Biochemical and Biophysical Research Communications 460 491-496. (https://doi.org/10.1016/j.bbrc.2015.03.153)
Johnston LW, Harris SB, Retnakaran R, Zinman B, Giacca A, Liu Z, Bazinet RP \& Hanley AJ 2016 Longitudinal associations of phospholipid and cholesteryl ester fatty acids With disorders underlying diabetes. Journal of Clinical Endocrinology and Metabolism 101 2536-2544. (https://doi.org/10.1210/jc.2015-4267)

Kahn SE, Hull RL \& Utzschneider KM 2006 Mechanisms linking obesity to insulin resistance and type 2 diabetes. Nature $\mathbf{4 4 4} 840-846$. (https://doi.org/10.1038/nature05482)

Kedi X, Ming Y, Yongping W, Yi Y \& Xiaoxiang Z 2009 Free cholesterol overloading induced smooth muscle cells death and activated both ER- and mitochondrial-dependent death pathway. Atherosclerosis $\mathbf{2 0 7}$ 123-130. (https://doi.org/10.1016/j.atherosclerosis.2009.04.019)

Lee JW, Huang JD \& Rodriguez IR 2015 Extra-hepatic metabolism of 7-ketocholesterol occurs by esterification to fatty acids via cPLA2 $\alpha$ and SOAT1 followed by selective efflux to HDL. Biochimica et Biophysica Acta 1851 605-619. (https://doi.org/10.1016/j.bbalip.2015.01.007)

Li J, Gu D, Lee SS, Song B, Bandyopadhyay S, Chen S, Konieczny SF, Ratliff TL, Liu X, Xie J, et al. 2016 Abrogating cholesterol esterification suppresses growth and metastasis of pancreatic cancer. Oncogene 35 6378-6388. (https://doi.org/10.1038/onc.2016.168)

Liu X, Zeng X, Chen X, Luo R, Li L, Wang C, Liu J, Cheng J, Lu Y \& Chen Y 2019 Oleic acid protects insulin-secreting INS-1E cells against palmitic acid-induced lipotoxicity along with an amelioration of ER stress. Endocrine 64 512-524. (https://doi. org/10.1007/s12020-019-01867-3)

Luna JM, Barajas JM, Teng KY, Sun HL, Moore MJ, Rice CM, Darnell RB \& Ghoshal K 2017 Argonaute CLIP defines a deregulated miR-122bound transcriptome that correlates with patient survival in human liver cancer. Molecular Cell 67 400-410.e7. (https://doi.org/10.1016/j. molcel.2017.06.025)

Montanya E \& Téllez N 2009 Pancreatic remodeling: beta-cell apoptosis, proliferation and neogenesis, and the measurement of beta-cell mass and of individual beta-cell size. Methods in Molecular Biology 560 137-158. (https://doi.org/10.1007/978-1-59745-448-3_11)

Motterle A, Gattesco S, Peyot ML, Esguerra JLS, Gomez-Ruiz A, Laybutt DR, Gilon P, Burdet F, Ibberson M, Eliasson L, et al. 2017 Identification of islet-enriched long non-coding RNAs contributing to $\beta$-cell failure in type 2 diabetes. Molecular Metabolism 6 1407-1418. (https://doi.org/10.1016/j.molmet.2017.08.005)

Nesca V, Guay C, Jacovetti C, Menoud V, Peyot ML, Laybutt DR, Prentki M \& Regazzi R 2013 Identification of particular groups of microRNAs that positively or negatively impact on beta cell function in obese models of type 2 diabetes. Diabetologia 56 2203-2212. (https://doi.org/10.1007/s00125-013-2993-y)

Prentki M \& Nolan CJ 2006 Islet beta cell failure in type 2 diabetes. Journal of Clinical Investigation 116 1802-1812. (https://doi. org/10.1172/JCI29103)

Rybak-Wolf A, Stottmeister C, Glažar P, Jens M, Pino N, Giusti S, Hanan M, Behm M, Bartok O, Ashwal-Fluss R, et al. 2015 Circular RNAs in the mammalian brain are highly abundant, conserved, and dynamically expressed. Molecular Cell 58 870-885. (https://doi. org/10.1016/j.molcel.2015.03.027)

Salzman J, Chen RE, Olsen MN, Wang PL \& Brown PO 2013 Cell-type specific features of circular RNA expression. PLoS Genetics 9 e1003777. (https://doi.org/10.1371/journal.pgen.1003777)

Schofield CJ \& Sutherland C 2012 Disordered insulin secretion in the development of insulin resistance and Type 2 diabetes. Diabetic Medicine 29 972-979. (https://doi. org/10.1111/j.1464-5491.2012.03655.x)

Starke S, Jost I, Rossbach O, Schneider T, Schreiner S, Hung LH \& Bindereif A 2015 Exon circularization requires canonical splice signals. Cell Reports 10 103-111. (https://doi.org/10.1016/j. celrep.2014.12.002)

Stoll L, Sobel J, Rodriguez-Trejo A, Guay C, Lee K, Venø MT, Kjems J, Laybutt DR \& Regazzi R 2018 Circular RNAs as novel regulators of

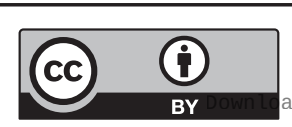

This work is licensed under a Creative Commons Attribution 4.0 International License. ded from Bioscientifica.com at 04/26/2023 11:17:17AM 
$\beta$-cell functions in normal and disease conditions. Molecular Metabolism 9 69-83. (https://doi.org/10.1016/j.molmet.2018.01.010)

Stopsack KH, Gerke TA, Andrén O, Andersson SO, Giovannucci EL, Mucci LA \& Rider JR 2017 Cholesterol uptake and regulation in high-grade and lethal prostate cancers. Carcinogenesis 38 806-811. (https://doi.org/10.1093/carcin/bgx058)

Suzuki H, Zuo Y, Wang J, Zhang MQ, Malhotra A \& Mayeda A 2006 Characterization of RNase R-digested cellular RNA source that consists of lariat and circular RNAs from pre-mRNA splicing. Nucleic Acids Research 34 e63. (https://doi.org/10.1093/nar/gkl151)

Xiong L, Gong Y, Wu L, Li J, He W, Zhu X \& Xiao H 2020 LncRNAMalat1 is involved in lipotoxicity-induced $\beta$-cell dysfunction and the therapeutic effect of exendin-4 via Ptbp1. Endocrinology 161 bqaa065. (https://doi.org/10.1210/endocr/bqaa065)

Xu H, Guo S, Li W \& Yu P 2015 The circular RNA Cdr1as, via miR-7 and its targets, regulates insulin transcription and secretion in islet cells. Scientific Reports 5 12453. (https://doi.org/10.1038/srep12453)

Xu T, Wu J, Han P, Zhao Z \& Song X 2017 Circular RNA expression profiles and features in human tissues: a study using RNA-seq data. BMC Genomics 18 680. (https://doi.org/10.1186/s12864-017-4029-3)

Yang Y, Gao X, Zhang M, Yan S, Sun C, Xiao F, Huang N, Yang X, Zhao K, Zhou H, et al. 2018 Novel role of FBXW7 circular RNA in repressing glioma tumorigenesis. Journal of the National Cancer Institute 110 304-315. (https://doi.org/10.1093/jnci/djx166)

You X \& Conrad TO 2016 Acfs: accurate circRNA identification and quantification from RNA-Seq data. Scientific Reports 638820. (https://doi.org/10.1038/srep38820)
You X, Vlatkovic I, Babic A, Will T, Epstein I, Tushev G, Akbalik G, Wang M, Glock C, Quedenau C, et al. 2015 Neural circular RNAs are derived from synaptic genes and regulated by development and plasticity. Nature Neuroscience 18 603-610. (https://doi.org/10.1038/ nn.3975)

Yue S, Li J, Lee SY, Lee HJ, Shao T, Song B, Cheng L, Masterson TA, Liu X, Ratliff TL, et al. 2014 Cholesteryl ester accumulation induced by PTEN loss and PI3K/AKT activation underlies human prostate cancer aggressiveness. Cell Metabolism 19 393-406. (https://doi. org/10.1016/j.cmet.2014.01.019)

Zhang Y, Zhang XO, Chen T, Xiang JF, Yin QF, Xing YH, Zhu S, Yang L $\&$ Chen LL 2013 Circular intronic long noncoding RNAs. Molecular Cell 51 792-806. (https://doi.org/10.1016/j.molcel.2013.08.017)

Zhang M, Huang N, Yang X, Luo J, Yan S, Xiao F, Chen W, Gao X, Zhao K, Zhou H, et al. 2018a A novel protein encoded by the circular form of the SHPRH gene suppresses glioma tumorigenesis. Oncogene 37 1805-1814. (https://doi.org/10.1038/s41388-017-0019-9)

Zhang M, Zhao K, Xu X, Yang Y, Yan S, Wei P, Liu H, Xu J, Xiao F, Zhou H, et al. 2018b A peptide encoded by circular form of LINCPINT suppresses oncogenic transcriptional elongation in glioblastoma. Nature Communications 9 4475. (https://doi. org/10.1038/s41467-018-06862-2)

Zheng Q, Bao C, Guo W, Li S, Chen J, Chen B, Luo Y, Lyu D, Li Y, Shi G, et al. 2016 Circular RNA profiling reveals an abundant circHIPK3 that regulates cell growth by sponging multiple miRNAs. Nature Communications 7 11215. (https://doi.org/10.1038/ ncomms11215)

Received in final form 9 August 2020

Accepted 11 September 2020

Accepted Manuscript published online 11 September 2020
(C) 2020 The authors Published by Bioscientifica Ltd. Printed in Great Britain
This work is licensed under a Creative Commons Attribution 4.0 International License.

ded from Bioscientifica.com at $04 / 26 / 2023$ 11:17:17AM 